\title{
The analysis and shooting reconstruction of the ricocheted shotgun pellet wounds
}

\author{
(1) Gökhan İbrahim Öğünç, Ph.D., ${ }^{1}$ Mustafa Tahir Özer, M.D., ${ }^{2} \oplus$ Ali İhsan Uzar, M.D., ${ }^{2}$ \\ (D) Mehmet Eryılmaz, M.D., ${ }^{2}$ (이 Mustafa Mercan, M.Sc. ${ }^{3}$
}

\author{
${ }^{1}$ Gendarmerie and Coast Guard Academy, Institute of Security Sciences, Ankara-Turkey \\ ${ }^{2}$ Department of General Surgery, Gülhane Training and Research Hospital, Ankara-Turkey \\ ${ }^{3}$ Department of Forensics, General Command of Gendarmerie, Ankara-Turkey
}

\begin{abstract}
BACKGROUND: In this study, a 35 years old man was killed with the ricocheted shotgun pellets wounds from the asphalt road surface. The Public Prosecutor to define the ricochet point requested the ricocheted pellet pattern examination in two different ricochet distances.

METHODS: The ten ricochet tests were performed for at 2 meters (point A) and I meter (point B) from the target, and the pellet distribution and pattern area were calculated using the gauss method. Then, the test and autopsy results were compared in the pellet number, calculated pellet pattern area and ricocheted angle. Furthermore, the similarity of the pellet number and the pellet pattern areas were examined using the two-tailed Mann-Whitney $U$ test.

RESULTS: In this study, $8 \mathrm{I}$ pellets recovered from the victim's body and the distribution pattern of pellets area was $2134 \mathrm{~cm}^{2}$. At the ricochet point $A$, the average number of pellets on the target was 82.1 and the distribution pattern of pellets area was $2700 \mathrm{~cm}^{2}$. At the ricochet point $B$, the average number of pellets on the target was 132.6 and the distribution pattern of pellets area was 4928 $\mathrm{cm}^{2}$. According to the two-tailed Mann-Whitney $U$ test, there was low-level similarity $(p<0.05$ level Sig. $0.023 ; z=-2.424)$ on the pellet pattern area between autopsy and the ricochet point A. However, as regards the pellet number on the target, there was a similarity ( $p<0.05$ level Sig. $0.481 ; z=-0.808$ ) between autopsy and the ricochet point $A$.
\end{abstract}

CONCLUSION: Test results showed that the pellet ricochet occurred two meters from the victim.

Keywords: Pellet ricochet; shooting reconstruction; shotgun wounds; wound ballistics.

\section{INTRODUCTION}

The external and terminal ballistics issues of the shotgun ammunition are different from the rifling barrel firearms ammunition. ${ }^{[1]}$ Owing to the weight and morphology of pellets, the flight and the target pattern of the birdshot and buckshot are the more influenced by the wind direction and velocity, air density, humidity, temperature, the wads' design, intermediary target, and ricochet effects than rifling firearms bullets. Additionally, the choke constriction of the smooth barrel directly impacts the pellet distribution..$^{[1,2]}$
Most of the projectiles can be deformed upon an impact with the unyielding and hard surface, but the lead pellets are more vulnerable to a collision than other projectiles. Furthermore, after ricochet, the shotgun pellets have a collision risk with each other and a billiard ball effect will occur. ${ }^{[3,4]}$ In these circumstances, the pellet distribution increases and it is a wide and parallel pattern to the surface on the target in the close range. ${ }^{[I]}$ The ricochet surface's structure and specifications also will affect pellet behavior. Because of these independent

Cite this article as: Öğünç Gİ, Özer MT, Uzar Aİ, Eryılmaz M, Mercan M. The analysis and shooting reconstruction of the ricocheted shotgun pellet wounds. Ulus Travma Acil Cerrahi Derg 2020;26:911-919.

Address for correspondence: Gökhan İbrahim Öğünç, Ph.D.

İncek Şehit Savcı Mehmet Selim Kiraz Bulvarı, Beytepe, 06805 Çankaya, Ankara, Turkey

Tel: +90 312 - 4647474 E-mail: gokhan.ogunc@gmail.com

Ulus Travma Acil Cerrahi Derg 2020;26(6):91I-919 DOI: 10.14744/tjtes.2020.76960 Submitted: 01.07.2019 Accepted: 14.01.2020 Online: 26.10 .2020

Copyright 2020 Turkish Association of Trauma and Emergency Surgery 
conditions, the calculation of the ricocheted pellet flight line and distribution pattern is a complicated and unpredictable forensic analysis. ${ }^{[5,6]}$

As a general rule, to perform the precise shooting reconstruction and asses the range, the firearm used in the crime with the same brand and type ammunition should be used in the tests. In the ricocheted shotgun pellet reconstruction study, the test results are compared with the crime scene or the shotgun wound pattern. Using the same firearm and same brand/type ammunition and testing on the same or similar ricochet surface will be assisted in controlling the independent and unpredictable conditions. ${ }^{[7,8]}$

In this study, a 35 years old man was killed by the ricocheted shotgun pellet wounds from the asphalt road surface. The crime scene examination unit found two suspicious deformation points on the asphalt surface as the pellet ricochet point. In order to define the pellet ricocheted point, the Public Prosecutor demanded to perform the ricocheted pellet pattern examination (shooting reconstruction) in these two different ricochet distance from the victim's position (Ricocheted Point " $A$ " is 2 meters from the victim's position and Ricocheted Point " $B$ " is I meter from the victim's position and comparing the test patterns with the pellet entrance wounds pattern on the victim body. According to the crime scene examination report, the distance between the victim and muzzle was 2.6 meters.

In the autopsy, 81 pellets recovered from $179 \mathrm{~cm}$ length victim's body. The distribution of the pellets was denser between the abdomen and femoral. According to the autopsy result, the death cause was multiple organ injuries.

\section{MATERIALS AND METHODS}

\section{The Location of the Pellet Entrance Wounds}

To obtain the correct locations of the shotgun pellets' entrance wounds on the victim body, the standard photogrammetric techniques were used on the scaled external autopsy photographs. For correction, the lens distortion error of the external autopsy photographs, the "wrapping" process was applied. ${ }^{[9]}$ Subsequently, the Cartesian coordinate system and scaled grid $(\mathrm{mm})$ were placed on the scaled external autopsy photographs using the software. For these processes, Adobe Photoshop CS6 software was used. The entrance wounds' coordinates recorded to the scaled body illustration for obtaining the pellet pattern on the victim's body (Fig. I).

\section{Weapon and Ammunition}

The tests were performed with the same shotgun used in the crime incident. The shotgun was break action, \# 12/70 gauge, and single smooth barrel without any a choke constriction (Cylinder Choke). To perform the ricochet tests, the Public Prosecutor office provided 10 cartridges, which were seized from the suspect. For reaching the significant test results, additionally, I 5 cartridges were taken from the Turkish National Police (TNP) Forensic Department ammunition collection. All these 15 cartridges were the same brand and type with the crime incident sample. The technical specifications of these cartridges are mentioned in Table I.

\section{Test Setup}

In the ricocheted pellet distribution test, the distance between the silhouette target and the shooting line was 2.6 meters. In this range, two ricocheted point was measured and marked on the asphalt surface. The first ricochet point, " $A$ " was 2 meters from the silhouette target line and the second ricochet point " $B$ " was I meter from the silhouette target line (Fig. 2). In the ricocheted pellet distribution tests,

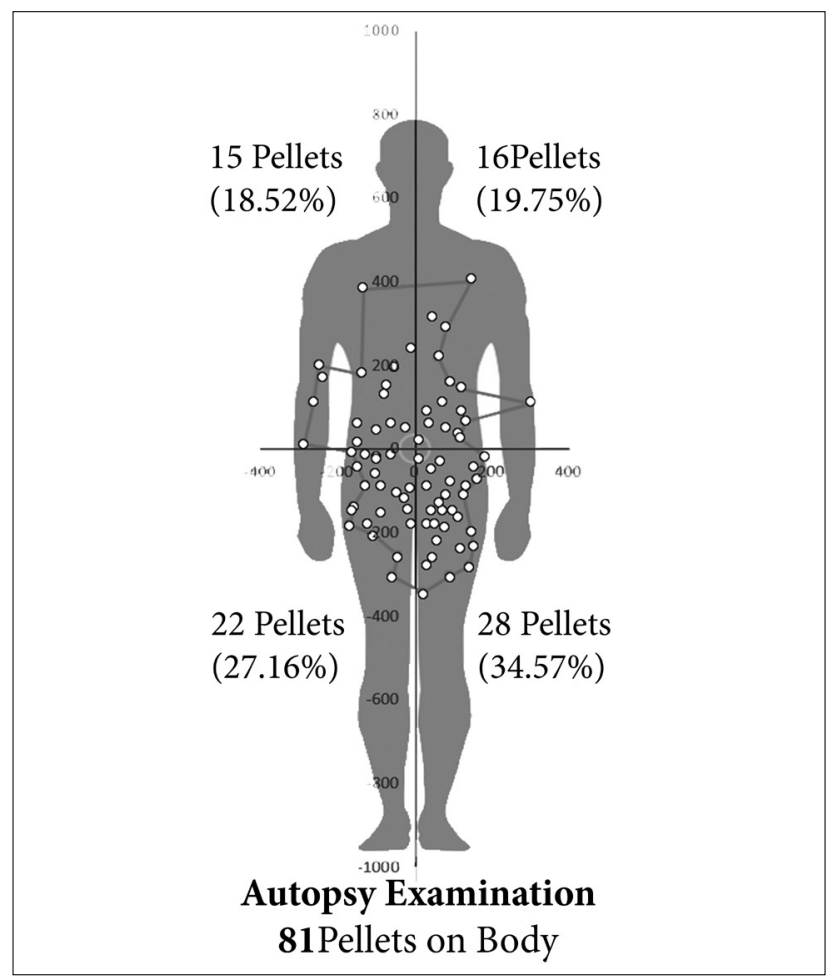

Figure 1. The pellet pattern on the victim's body.

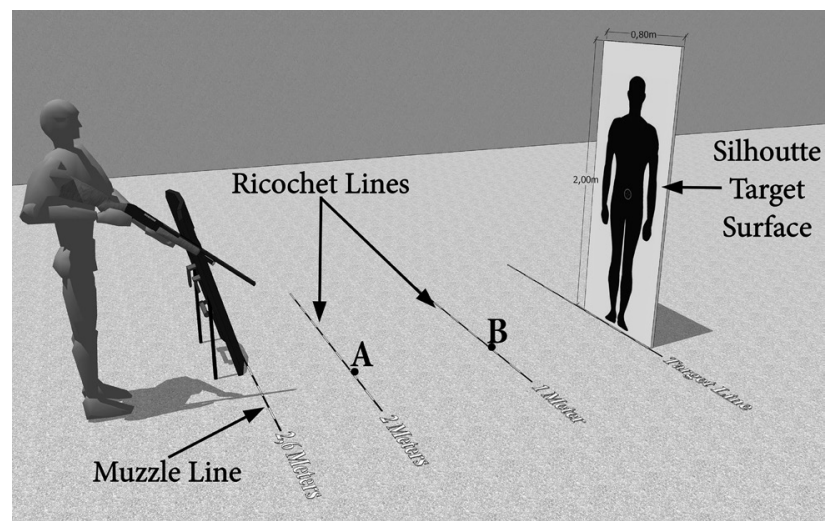

Figure 2. The ricocheted pellet test setup and ricocheted points (A and $B$ ). 
Table I. The technical specifications of the test ammunition

\begin{tabular}{llll}
\hline Cartridge Gauge & 12 & Cartridge Brand & Straling \\
Pellet Size / Type & \#4 Birdshot / Lead & Pellet Weight & 0.22 grams \\
Pellet Diameter & $3.25 \mathrm{~mm}$ & Number of Pellets in the Cartridges & 144 \\
Wad Type & B\&PH2I Cup & Pellet Velocity & $390 \pm 10 \mathrm{~m} / \mathrm{s}$ (Manufacture Spec.) \\
\hline
\end{tabular}

Table 2. The test setup specifications and ricochet points' information

\begin{tabular}{|c|c|c|}
\hline \multirow[t]{5}{*}{ Ist Ricochet Point (A) (2 meters from target) } & Muzzle to Ricochet Point Distance & $92 \mathrm{~cm}$ \\
\hline & Shooting Line to Ricochet Point Distance & $60 \mathrm{~cm}$ \\
\hline & Muzzle Height & $70 \mathrm{~cm}$ \\
\hline & Muzzle Angle & $40^{\circ}$ \\
\hline & Incident Angle & $50^{\circ}$ \\
\hline \multirow[t]{5}{*}{$2^{\text {nd }}$ Ricochet Point (B) (I meter from target) } & Muzzle to Ricochet Point Distance & $183 \mathrm{~cm}$ \\
\hline & Shooting Line to Ricochet Point Distance & $160 \mathrm{~cm}$ \\
\hline & Muzzle Height & $70 \mathrm{~cm}$ \\
\hline & Muzzle Angle & $60^{\circ}$ \\
\hline & Incident Angle & $30^{\circ}$ \\
\hline
\end{tabular}

the plywood panels (size: $200 \mathrm{~cm} \times 80 \mathrm{~cm}$ ) covered with the silhouette target paper were used as a test target.

To reach the significant test results, ten silhouette targets were used for each ricochet distance and only the one test fire made on each target. The fourth of the cartridges were provided from the suspect and the rest of the cartridges (six cartridges were the same brand and type with the crime incident sample) were from the TNP Forensic Department ammunition collection. After each test fire, the ricochet point moved $20 \mathrm{~cm}$ left; these proses were applied for all the ricochet distances (Table 2).

There was not any information about the ricochet asphalt surface structure in the crime scene examination report. For that reason, the tests were performed on the concrete type asphalt (aggregate $93 \%-97 \%$ and bitumen $7 \%-3 \%$ ), which is a common asphalt type in Turkey. ${ }^{[10]}$

\section{Evaluation of the Test Results}

For assessing the possible ricochet point, the ricochet pattern tests' results were evaluated in the four phases. In the first phase, the silhouette targets were separated into the Cartesian coordinate system regions. Subsequently, the number of pellets in each Cartesian coordinate system region was counted, and for determining the patterns (victim's body and test target patterns), the average number of pellets was calculated. Then, the test results were compared with the autopsy report result. Because the real position of the victim was unknown, all of the pellet's hits (not only the inner silhouette target border hits) on the target were taken account in the ricochet tests. Additionally, the ricochet angles were calculated for each possible ricochet point and compared with the autopsy report result.

In the second phase, the pellet pattern on the victim's body and the ricocheted pellet test patterns were calculated with the Gauss Area Calculation (Shoelace Formula ${ }^{\left[{ }^{[I]}\right.}$ ) and the results were compared (Equation I).

$$
A=\frac{1}{2}\left|\sum_{i=1}^{n-1} x_{i} y_{i+1}+x_{n} y_{1}-\sum_{i=1}^{n-1} x_{i+1} y_{i}-x_{1} y_{n}\right|
$$

$A=\frac{1}{2}\left|x_{1} y_{2}+x_{2} y_{3}+\cdots+x_{n-1} y_{n}+x_{n} y_{1}-x_{2} y_{1}-x_{3} y_{2}-\cdots-x_{n} y_{n-1}-x_{1} y_{n}\right|$

Equation I. The shoelace equation.

In the third phase, to obtain the overall distribution pattern, all the silhouette target patterns were overlapping and comparing with the anatomic distribution of the pattern on the victim's body.

In the last phase, to statistically examine the similarity of the test results with the autopsy results, the two-tailed Mann-Whitney $U$ test was used on the IBM SPSS version 20 Software.

\section{RESULTS}

As mentioned in the test setup, the ricocheted pellet distribution tests were performed on the two different ricochet points. It seemed in the overall evaluation of the test results that the pellet hits on all targets were in the scattered pattern. 


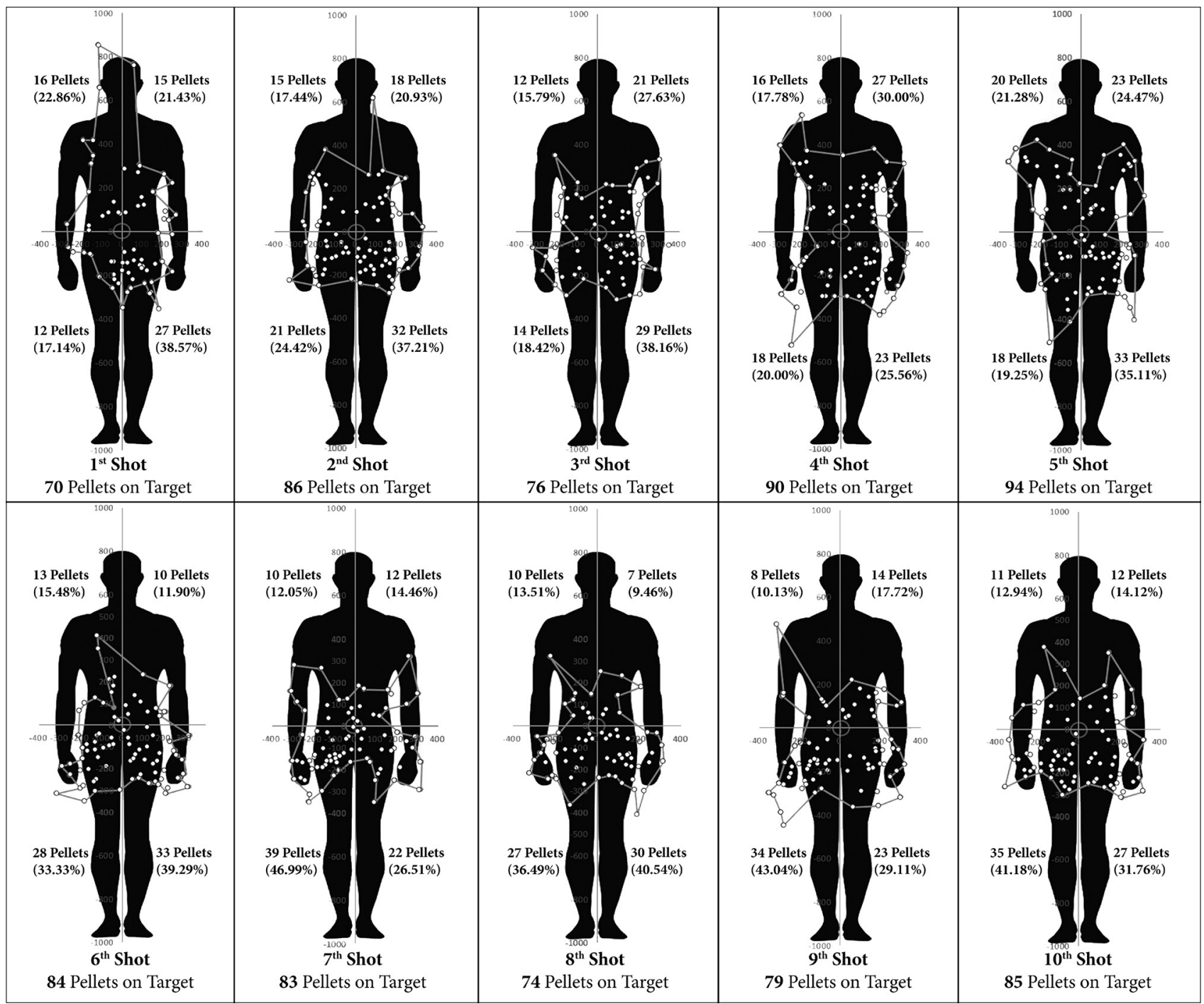

Figure 3. The first ricochet point "A" test results patterns and pellet distribution area.

\section{The First Ricochet Point "A" Test Results (2 Meters from the Target)}

Ten test shots were made at the " $A$ " ricochet distance $(2$ meters from the target). In these tests, the average number of pellets on the target was 82.1 (57\% of the total pellet number in the cartridge); the distribution of the pellets was denser between the abdomen and femoral with 64.20\% (Fig. 3) (Table 3); and the Gauss Method calculated the average area of the distribution pattern of pellets was $2700 \mathrm{~cm}^{2}(\mathrm{Ta}-$ ble 4). The ricochet angles were calculated; the average of the lowest ricochet angle was $16.9^{\circ}$, and the average of the highest ricochet angle was $36.1^{\circ}$ (Table 3) (Fig. 4).

\section{The Second Ricochet Point "B" Test Results (1 Meter from the Target)}

Ten test shots were made at the "B" ricochet distance (I meter from the target). In these tests, the average number of pellets on the target was 132.6 (92\% of the total pellet number in the cartridge the distribution of the pellets was denser between umbilical line and Crural with $83.54 \%$, and the $16.46 \%$ of the pellets hit the between the chest and umbilical line area (Fig. 5) (Table 5); and the Gauss Method calculated the average area of the distribution pattern of pellets was $4928 \mathrm{~cm}^{2}$ (Table 6). The ricochet angles were calculated; the average of the lowest ricochet angle was 16.10, and the average of the highest ricochet angle was $56.4^{\circ}$ (Table 5) (Fig. 6).

For the general evaluation of the ricocheted pellet distribution patterns, the distribution patterns of each ricochet point tests were overlapped and obtained the overall pattern (Fig. 7). Subsequently, these overlapping results compared with the anatomic distribution of the pattern on the victim's body (Table 7).

The overlapping of the ten test shots on the " $A$ " ricochet point totally 821 pellets hit the target and the average pellet distribution area was $2772 \mathrm{~cm}^{2}$. The total pellet number on the target of the ten test shots on the " $\mathrm{B}$ " ricochet point was 
Table 3. The "A" ricochet point test results

\begin{tabular}{|c|c|c|c|c|c|c|c|c|c|c|c|}
\hline \multirow[t]{2}{*}{ Test Shots } & \multicolumn{2}{|c|}{ Ricochet Angle } & \multirow{2}{*}{$\begin{array}{c}\text { The } \\
\text { Total Pellet } \\
\text { Number on } \\
\text { the Targe }\end{array}$} & \multicolumn{2}{|c|}{$\begin{array}{c}\text { Ist Cartesian } \\
\text { Coordinate System } \\
\text { Region }\end{array}$} & \multicolumn{2}{|c|}{$\begin{array}{c}2^{\text {nd }} \text { Cartesian } \\
\text { Coordinate System } \\
\text { Region }\end{array}$} & \multicolumn{2}{|c|}{$\begin{array}{l}3^{\text {rd }} \text { Cartesian } \\
\text { Coordinate } \\
\text { System Region }\end{array}$} & \multicolumn{2}{|c|}{$\begin{array}{l}4^{\text {th }} \text { Cartesian } \\
\text { Coordinate } \\
\text { System Region }\end{array}$} \\
\hline & $\begin{array}{l}\text { The } \\
\text { Lowest } \\
\text { Ricochet }\end{array}$ & $\begin{array}{l}\text { The } \\
\text { Highest } \\
\text { Ricochet }\end{array}$ & & $\begin{array}{c}\text { Number } \\
\text { of } \\
\text { Pellets }\end{array}$ & $\begin{array}{l}\text { Percentage } \\
\text { of Pellet } \\
\text { Distribution }\end{array}$ & $\begin{array}{c}\text { Number } \\
\text { of } \\
\text { Pellets }\end{array}$ & $\begin{array}{l}\text { Percentage } \\
\text { of Pellet } \\
\text { Distribution }\end{array}$ & $\begin{array}{c}\text { Number } \\
\text { of } \\
\text { Pellets }\end{array}$ & $\begin{array}{l}\text { Percentage } \\
\text { of Pellet } \\
\text { Distribution }\end{array}$ & $\begin{array}{c}\text { Number } \\
\text { of } \\
\text { Pellets }\end{array}$ & $\begin{array}{l}\text { Percentage } \\
\text { of Pellet } \\
\text { Distribution }\end{array}$ \\
\hline Test \# I & $17.8^{\circ}$ & 42.7 & 70 & 15 & $21.43 \%$ & 16 & $22.86 \%$ & 12 & $17.14 \%$ & 27 & $38.57 \%$ \\
\hline Test \#2 & $19.6^{\circ}$ & $38.9^{\circ}$ & 86 & 18 & $20.93 \%$ & 15 & $17.44 \%$ & 21 & $24.42 \%$ & 32 & $37.21 \%$ \\
\hline Test \#3 & $18.9^{\circ}$ & $34.0^{\circ}$ & 76 & 21 & $27.63 \%$ & 12 & $15.79 \%$ & 14 & $18.42 \%$ & 29 & $38.16 \%$ \\
\hline Test \#4 & $13.3^{\circ}$ & $37.5^{\circ}$ & 90 & 27 & $30.00 \%$ & 16 & $17.78 \%$ & 18 & $20.00 \%$ & 23 & $25.56 \%$ \\
\hline Test \#5 & $13.7^{\circ}$ & $35.3^{\circ}$ & 94 & 23 & $24.47 \%$ & 20 & $21.28 \%$ & 18 & $19.15 \%$ & 33 & $35.11 \%$ \\
\hline Test \#6 & $18.0^{\circ}$ & $35.1^{\circ}$ & 84 & 10 & $11.90 \%$ & 13 & $15.48 \%$ & 28 & $33.33 \%$ & 33 & $39.29 \%$ \\
\hline Test \#7 & $18.0^{\circ}$ & $33.4^{\circ}$ & 83 & 12 & $14.46 \%$ & 10 & $12.05 \%$ & 39 & $46.99 \%$ & 22 & $26.51 \%$ \\
\hline Test \#8 & $16.4^{\circ}$ & $33.4^{\circ}$ & 74 & 7 & $9.46 \%$ & 10 & $13.51 \%$ & 27 & $36.49 \%$ & 30 & $40.54 \%$ \\
\hline Test \#9 & $15.3^{\circ}$ & $36.4^{\circ}$ & 79 & 14 & $17.72 \%$ & 8 & $10.13 \%$ & 34 & $43.04 \%$ & 23 & $29.11 \%$ \\
\hline Test \#10 & $18.9^{\circ}$ & $34.5^{\circ}$ & 85 & 12 & $14.12 \%$ & 11 & $12.94 \%$ & 35 & $41.18 \%$ & 27 & $31.76 \%$ \\
\hline Average & $16.9^{\circ}$ & $36.1^{\circ}$ & 82.1 & 15.9 & $19.21 \%$ & 13.1 & $15.92 \%$ & 24.6 & $30.01 \%$ & 27.9 & $34.18 \%$ \\
\hline Std. Dev. & 2.22 & 2.98 & 7.38 & 6.26 & 6.84 & 3.63 & 4.02 & 9.38 & 11.47 & 4.20 & 5.54 \\
\hline Std. Err. Mean & 0.7 & 0.92 & 2.33 & 1.98 & 2.16 & 1.14 & 1.27 & 2.96 & 3.62 & 1.32 & 1.75 \\
\hline
\end{tabular}

Table 4. The Gauss method calculated the area of pellet distribution pattern of the ricochet point " $A$ " tests

\begin{tabular}{lccc}
\hline Test Shots & Calculated Area by Gauss Method & Test Shots & Calculated Area by Gauss Method \\
\hline Test \#I & $3254 \mathrm{~cm}^{2}$ & Test \#6 & $2384 \mathrm{~cm}^{2}$ \\
Test \#2 & $2802 \mathrm{~cm}^{2}$ & Test \#7 & $2438 \mathrm{~cm}^{2}$ \\
Test \#3 & $2118 \mathrm{~cm}^{2}$ & Test \#8 & $2118 \mathrm{~cm}^{2}$ \\
Test \#4 & $3380 \mathrm{~cm}^{2}$ & Test \#9 & $2868 \mathrm{~cm}^{2}$ \\
Test \#5 & $3128 \mathrm{~cm}^{2}$ & Test \#10 & $2732 \mathrm{~cm}^{2}$ \\
The Average of 10 Test Shots & & $2722 \mathrm{~cm}^{2}$ \\
The Standard Deviation of 10 Test Shots & & & $451.3 \mathrm{~cm}^{2}$ \\
Standard Error of The Mean of 10 Test Shots & & $142.7 \mathrm{~cm}^{2}$ \\
\hline
\end{tabular}

1326, and the average pellet distribution area was $4928 \mathrm{~cm}^{2}$. According to these results, the " $A$ " ricochet point test results were similar to the autopsy results.

To statistically examine the similarity of the ricochet pellet distribution pattern with the autopsy examination results (pellet pattern on the victim body), the two-tailed Mann-Whitney $U$ test was applied to test pairs.

Concerning the calculated pellet distribution pattern area, the similarity between the first ricochet point $(A)$ test results and the autopsy examination result is low level $(p<0.05$ level Sig. 0.023; $z=-2.424$ ). However, as regards the pellet number on the target, there is a similarity $(p<0.05$ level Sig. $0.481 ; z=-$ 0.808 ) between the first ricochet point $(A)$ test results and the autopsy examination results.
Concerning the calculated pellet distribution pattern area, there is not a similarity between the second ricochet point (B) test results and the autopsy examination result $(p<0.05$

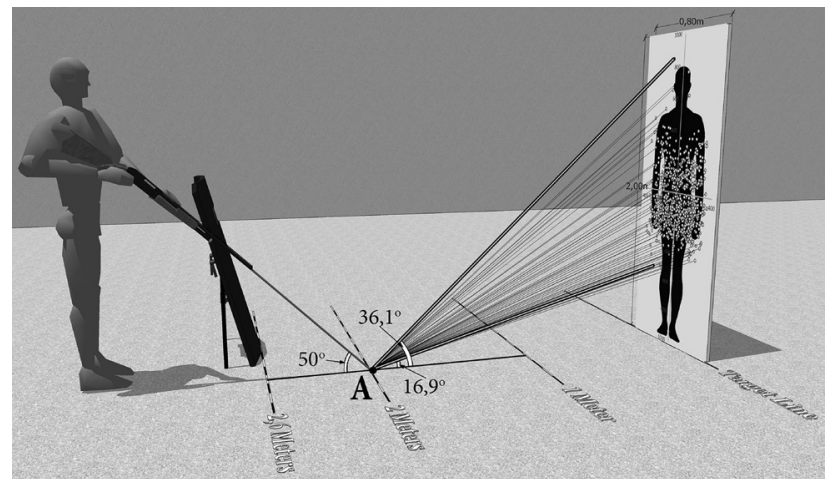

Figure 4. The first ricochet point " $A$ " the averages lowest and highest pellet ricochet angles of 10 test tests. 


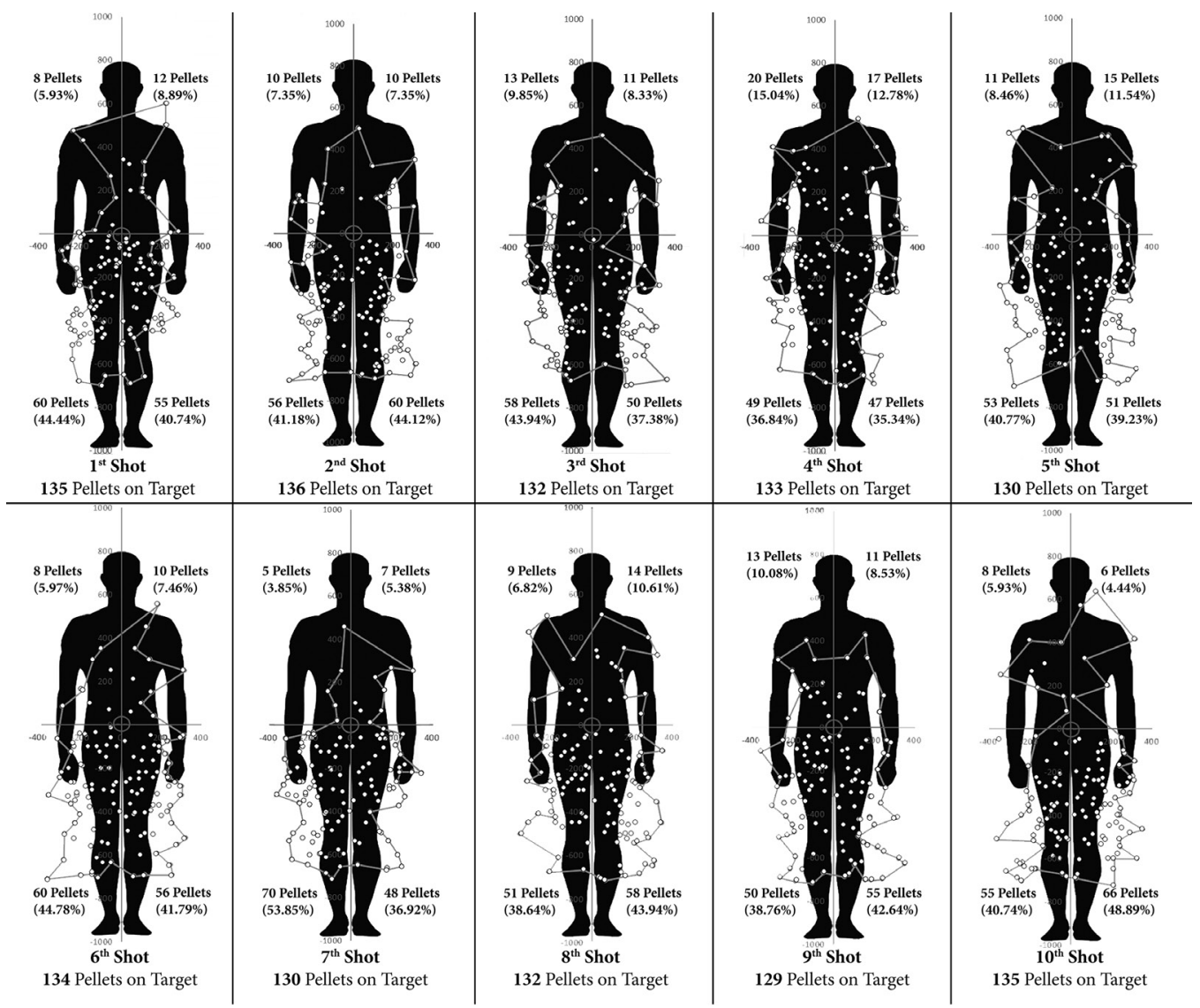

Figure 5. The second ricochet point "B" test results patterns and pellet distribution area.

level Sig. 0.000; $z=-4.038$ ), and also concerning the pellet number on the target, there is not a similarity $(p<0.05$ level
Sig. 0.000; $z=-4.044$ ) between the second ricochet point (B) test results and the autopsy examination result.

Table 5. The "B" ricochet point test results

\begin{tabular}{|c|c|c|c|c|c|c|c|c|c|c|c|}
\hline \multirow[t]{2}{*}{ Test Shots } & \multicolumn{2}{|c|}{ Ricochet Angle } & \multirow{2}{*}{$\begin{array}{c}\text { The } \\
\text { Total Pellet } \\
\text { Number on } \\
\text { the Targe }\end{array}$} & \multicolumn{2}{|c|}{$\begin{array}{c}\text { Ist Cartesian } \\
\text { Coordinate System } \\
\text { Region }\end{array}$} & \multicolumn{2}{|c|}{$\begin{array}{c}2^{\text {nd }} \text { Cartesian } \\
\text { Coordinate System } \\
\text { Region }\end{array}$} & \multicolumn{2}{|c|}{$\begin{array}{c}3^{\text {rd }} \text { Cartesian } \\
\text { Coordinate } \\
\text { System Region }\end{array}$} & \multicolumn{2}{|c|}{$\begin{array}{c}4^{\text {th }} \text { Cartesian } \\
\text { Coordinate } \\
\text { System Region }\end{array}$} \\
\hline & $\begin{array}{c}\text { The } \\
\text { Lowest } \\
\text { Ricochet }\end{array}$ & $\begin{array}{l}\text { The } \\
\text { Highest } \\
\text { Ricochet }\end{array}$ & & $\begin{array}{l}\text { Number } \\
\text { of } \\
\text { Pellets }\end{array}$ & $\begin{array}{l}\text { Percentage } \\
\text { of Pellet } \\
\text { Distribution }\end{array}$ & $\begin{array}{l}\text { Number } \\
\text { of } \\
\text { Pellets }\end{array}$ & $\begin{array}{l}\text { Percentage } \\
\text { of Pellet } \\
\text { Distribution }\end{array}$ & $\begin{array}{l}\text { Number } \\
\text { of } \\
\text { Pellets }\end{array}$ & $\begin{array}{c}\text { Percentage } \\
\text { of Pellet } \\
\text { Distribution }\end{array}$ & $\begin{array}{l}\text { Number } \\
\text { of } \\
\text { Pellets }\end{array}$ & $\begin{array}{l}\text { Percentage } \\
\text { of Pellet } \\
\text { Distribution }\end{array}$ \\
\hline Test \#I & $16.6^{\circ}$ & $57.9^{\circ}$ & 135 & 12 & $8.89 \%$ & 8 & $5.93 \%$ & 60 & $44.44 \%$ & 55 & $40.74 \%$ \\
\hline Test \#2 & $16.4^{\circ}$ & $56.2^{\circ}$ & 136 & 10 & $7.35 \%$ & 10 & $7.35 \%$ & 56 & $41.18 \%$ & 60 & $44.12 \%$ \\
\hline Test \#3 & $16.6^{\circ}$ & $55.5^{\circ}$ & 132 & II & $8.33 \%$ & 13 & $9.85 \%$ & 58 & $43.94 \%$ & 50 & $37.88 \%$ \\
\hline Test \#4 & $16.6^{\circ}$ & $57.0^{\circ}$ & 133 & 17 & $12.78 \%$ & 20 & $15.04 \%$ & 49 & $36.84 \%$ & 47 & $35.34 \%$ \\
\hline Test \#5 & $16.4^{\circ}$ & $56.0^{\circ}$ & 130 & 15 & $11.54 \%$ & 11 & $8.46 \%$ & 53 & $40.77 \%$ & 51 & $39.23 \%$ \\
\hline Test \#6 & $15.9^{\circ}$ & $57.2^{\circ}$ & 134 & 10 & $7.46 \%$ & 8 & $5.97 \%$ & 60 & $44.78 \%$ & 56 & $41.79 \%$ \\
\hline Test \#7 & $16.0^{\circ}$ & $55.4^{\circ}$ & 130 & 7 & $5.38 \%$ & 5 & $3.85 \%$ & 70 & $53.85 \%$ & 48 & $36.92 \%$ \\
\hline Test \#8 & $15.9^{\circ}$ & $56.3^{\circ}$ & 132 & 14 & $10.61 \%$ & 9 & $6.82 \%$ & 51 & $38.64 \%$ & 58 & $43.94 \%$ \\
\hline Test \#9 & $15.9^{\circ}$ & $54.9^{\circ}$ & 129 & 11 & $8.53 \%$ & 13 & $10.08 \%$ & 50 & $38.76 \%$ & 55 & $42.64 \%$ \\
\hline Test \# 10 & $15.3^{\circ}$ & $58.5^{\circ}$ & 135 & 6 & $4.44 \%$ & 8 & $5.93 \%$ & 55 & $40.74 \%$ & 66 & $48.89 \%$ \\
\hline Average & $16.1^{\circ}$ & $56.4^{\circ}$ & 132.6 & 11.3 & $8.53 \%$ & 10.5 & $7.93 \%$ & 56.2 & $42.39 \%$ & 54.6 & $41.15 \%$ \\
\hline Std. Dev. & 0.42 & I.14 & 2.41 & 3.40 & $2.59 \%$ & 4.14 & $3.14 \%$ & 6.25 & $4.85 \%$ & 5.85 & $4.01 \%$ \\
\hline Std. Err. Mean & 0.13 & 0.36 & 0.76 & 1.07 & $0.82 \%$ & 1.31 & $0.99 \%$ & 1.97 & $1.53 \%$ & 1.8 & $1.27 \%$ \\
\hline
\end{tabular}




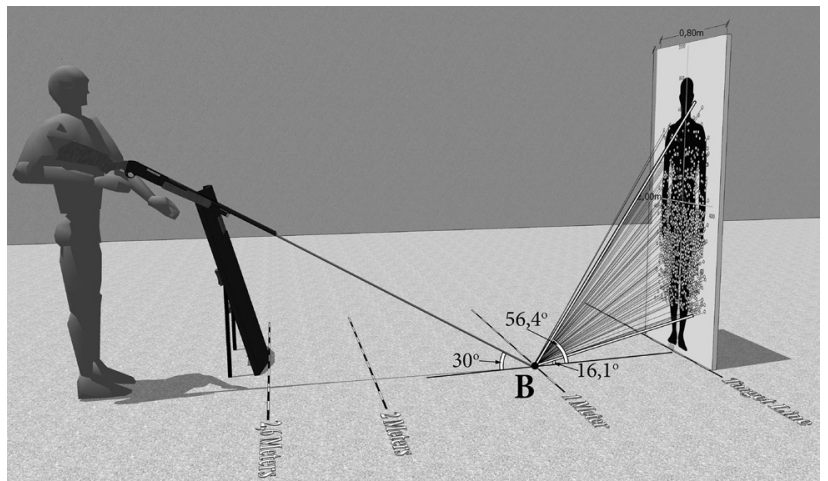

Figure 6. The second ricochet point "B" the average lowest and highest pellet ricochet angles of 10 test tests.

\section{DISCUSSION}

According to the autopsy report, $8 \mathrm{I}$ pellets $(56.2 \%$ of the total pellet number in the cartridge) recovered from the victim's body. The location of pellet hits was determined from the scaled and "wrapping" process applied photos of the victim's body. Afterward, the pellet entrance wounds and test fire pellet hit positions are placed/marked on the Cartesian coordinate system. The distribution of the $8 \mathrm{I}$ pellets was denser between the abdomen and femoral, with $61.73 \%$ at the victim's body. The Gauss Method calculated area of the distribution pattern of pellets was $2134 \mathrm{~cm}^{2}$ (Fig. I) on the victim's body.

The pellet ricochet tests were requested to perform in the two different distances (from target to muzzle I meter (rico-

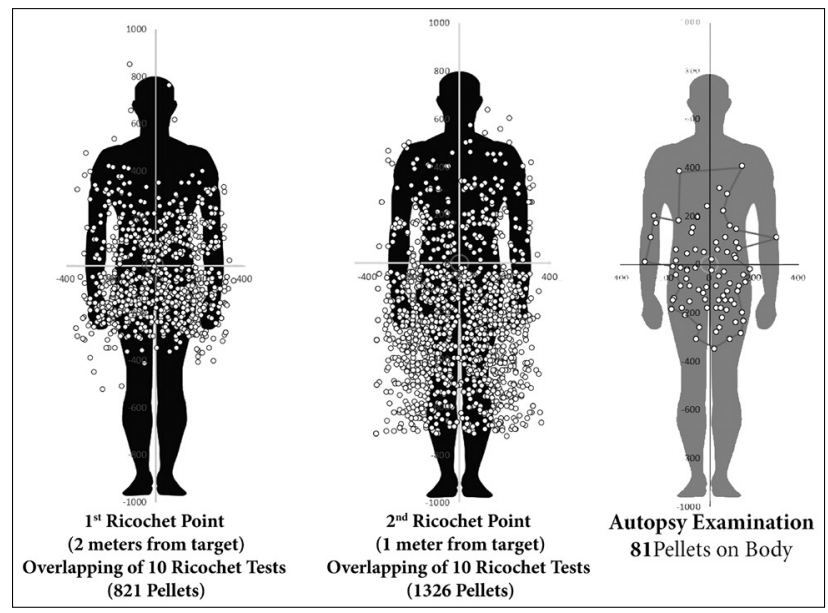

Figure 7. The overlapping of the ten test shots of the "A" and "B" ricochet points with the autopsy examination result.

chet point "A") and 2 meters (ricochet point "B") (Fig. 2). Ten test fire was made for both distances, then the pellet number and pattern area on the target were calculated. For the pellet pattern area calculation, Gauss Method was used (Table 7). To see the overall pattern of pellet, the pellet patterns of the ten test fires were overlapping on the one target (Fig. 7). This process made for each distance. Subsequently, the test results were compared with the autopsy examination result. To statistically examine the similarity of the ricochet test results with the autopsy result, the two-tailed Mann-Whitney $U$ test was used on the IBM SPSS version 20 Software.

Table 6. The Gauss method calculated the area of the pellet distribution pattern of the ricochet point "B" tests

\begin{tabular}{lccc}
\hline Test Shots & Calculated Area by Gauss Method & Test Shots & Calculated Area by Gauss Method \\
\hline Test \#I & $4102 \mathrm{~cm}^{2}$ & Test \#6 & $5194 \mathrm{~cm}^{2}$ \\
Test \#2 & $4946 \mathrm{~cm}^{2}$ & Test \#7 & $4205 \mathrm{~cm}^{2}$ \\
Test \#3 & $4844 \mathrm{~cm}^{2}$ & Test \#8 & $5572 \mathrm{~cm}^{2}$ \\
Test \#4 & $5243 \mathrm{~cm}^{2}$ & Test \#9 & $4925 \mathrm{~cm}^{2}$ \\
Test \#5 & $5250 \mathrm{~cm}^{2}$ & Test \#10 & $4971 \mathrm{~cm}^{2}$ \\
The Average of 10 Test Shots & & $4928 \mathrm{~cm}^{2}$ \\
The Standard Deviation of 10 Test Shots & & $459.8 \mathrm{~cm}^{2}$ \\
Standard Error of the Mean of 10 Test Shots & & $145.4 \mathrm{~cm}^{2}$ \\
\hline
\end{tabular}

Table 7. The average pellet number and pattern area results

\begin{tabular}{lcccccc}
\hline Ricochet Points & $\begin{array}{c}\text { The Average } \\
\text { Pellet } \\
\text { Number on } \\
\text { The Target }\end{array}$ & $\begin{array}{c}\mathbf{I}^{\text {st }} \text { Cartesian } \\
\text { Coordinate } \\
\text { System Region } \\
\text { Average Pellet } \\
\text { Distribution }\end{array}$ & $\begin{array}{c}\mathbf{2}^{\text {nd }} \text { Cartesian } \\
\text { Coordinate } \\
\text { System Region } \\
\text { Average Pellet } \\
\text { Distribution }\end{array}$ & $\begin{array}{c}\mathbf{3}^{\text {rd }} \text { Cartesian } \\
\text { Coordinate } \\
\text { System Region } \\
\text { Average Pellet } \\
\text { Distribution }\end{array}$ & $\begin{array}{c}\mathbf{4}^{\text {th }} \text { Cartesian } \\
\text { Coordinate } \\
\text { System Region } \\
\text { Average Pellet } \\
\text { Distribution }\end{array}$ & $\begin{array}{c}\text { Average Pellet } \\
\text { Distribution } \\
\text { Pattern Area } \\
\left(\mathbf{c m}^{2}\right)\end{array}$ \\
I $^{\text {st }}$ Ricochet Point A $(2 \mathrm{~m})$ & 82.1 & $15.9(19.21 \%)$ & $13.1(15.92 \%)$ & $24.6(30.02 \%)$ & $27.9(34.18)$ & 2722 \\
$2^{\text {nd }}$ Ricochet Point B $(\mathrm{Im})$ & 132.6 & $11.3(8.53 \%)$ & $10.5(7.93 \%)$ & $56.2(42.39 \%)$ & $54.6(41.15 \%)$ & 4928 \\
Autopsy examination & 81 & $16(19.75 \%)$ & $15(18.52 \%)$ & $22(27.16)$ & $28(34.57 \%)$ & 2134 \\
\hline
\end{tabular}




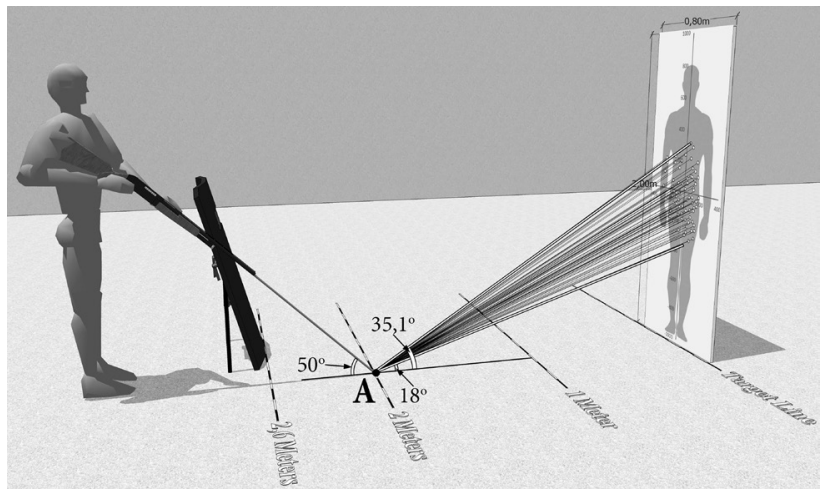

Figure 8. If the ricochet point was "A", the calculated lowest and highest pellet ricochet angle of the victim's body.

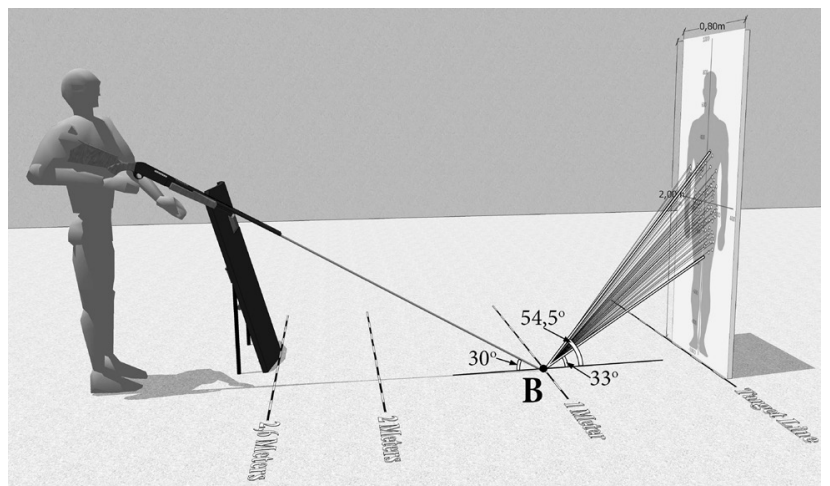

Figure 9. If the ricochet point was "B", the calculated lowest and highest pellet ricochet angle of the victim's body.

In the test results, it seems that while the ricochet point approaches to the target, the number of pellets increases and a wider pattern occurs on the target, and the lower line of the pattern is descended to the surface. Because when the distance between ricochet point and target become closer, the more pellet is hit the target; vice versa the more pellets escape from the sides of the target and the center of pellet mass are ascending.

In this context, each ricochet point test results were compared with the autopsy results:

a. The pellet number on the victim body was $8 \mathrm{I}$, the pellet distribution pattern area was $2134 \mathrm{~cm}^{2}$, and the pellet ricochet angles to the victim body were calculated in lowest and highest angle for both suspected ricochet point. If the point "A" accepted as a pellet ricocheted point, the calculated lowest pellet ricochet angle was $18^{\circ}$ and the highest ricochet angle was $35^{\circ}$ (Fig. 8). On the other hand, when the point " $B$ " was accepted as a pellet ricochet point, the calculated the lowest ricochet angle was $33^{\circ}$, and the highest ricochet angle was $54.5^{\circ}$ (Fig. 9).

b. The shooting reconstruction test for the first ricochet point "A" test, the pellets (average 82.1 pellets) hit the silhouette target with an irregular and wide pattern (average pattern area: $2722 \mathrm{~cm}^{2}$ ). The 64.20 percentage of the pellets were distributed between the abdomen and femoral region. And some of the pellets individually hit to the chest and head. The average lowest ricochet angle was $16.9^{\circ}$, and the highest ricochet angle was $36.1^{\circ}$ for the first ricochet point " $A$ ".

c. The shooting reconstruction test for the second ricochet point "B" test, the pellets (average I 32.6 pellets), also hit the silhouette target with irregular and wider pattern (average pattern area: $4928 \mathrm{~cm}^{2}$ ) than the first ricochet point tests and the autopsy results. The distribution of the pellets was denser between theumbilical line and Crural with 83.54 percentage. The average lowest ricochet angle was $16.1^{\circ}$, and the highest ricochet angle was $56.4 \div$ for the first ricochet point (B). The difference between the $2^{\text {nd }}$ ricochet point " $B$ " test patterns and the autopsy examination pattern was illustrated in Figure 7.

According to the two-tailed Mann-Whitney $U$ tests, there is a similarity between the first ricochet point " $A$ " test results and autopsy examination result concerning calculated pellet distribution pattern area $(p<0.05$ level Sig. 0.023; $z=-2.424)$ and the pellet number on the silhouette target $(p<0.05$ level Sig. $0.481 ; z=-0.808)$. However, there is not a similarity between the second ricochet point " $B$ " test results and autopsy examination result concerning calculated pellet distribution pattern area $(p<0.05$ level Sig. 0.000; $z=-4.038)$ and the pellet number on the silhouette target $(p<0.05$ level Sig. 0.000; $z=-4.044)$.

Consequently, according to the shooting reconstruction study results (numbers of pellet hits, the calculated pellet pattern area and the angles of the pellet ricochets) and the crime scene examination and the autopsy reports, it is evaluated that the pellet ricocheted, which caused the victim's death, occurred from the point " $A$ " ( 2 meters far away from the victim's position).

Peer-review: Internally peer-reviewed.

Authorship Contributions: Concept: G.I.Ö.; Design: G.i.Ö.; Supervision: G.i.Ö.; Resource: G.i.Ö.; Materials: G.i.Ö.; Data: G.I.Ö.; Analysis: G.I.Ö., M.T.Ö., A.I.U., M.E., M.M.; Literature search: G.I.Ö.; Writing: G.I.Ö., M.T.Ö.; Critical revision: M.E.

Conflict of Interest: None declared.

Financial Disclosure: The authors declared that this study has received no financial support.

\section{REFERENCES}

1. DiMaio VJM. Gunshot Wounds. 3rd edition. Boca Raton, FL: CRC Press; 2016.

2. Rinker RA. Understanding Firearms Ballistics Basic to Advanced Ballistics. 6th edition. Clarksville, IN: Mulberry House Publishing; 2008.

3. Haag MG, Haag LC. Shooting Incident Reconstruction. 2nd edition. San Diego, CA: Academic Press; 2011. [CrossRef]

4. Coe JI, Austin N. The effects of various intermediate targets on dispersion of shotgun patterns. Am J Forensic Med Pathol 1992;13:281-3. 
5. Hueske EF. Practical Analysis and Reconstruction of Shooting Incidents. 2nd edition. Boca Raton, FL: CRC Press; 2016.

6. Gardner RM, Bevel T. Practical Crime Scene Analysis and Reconstruction. Boca Raton, FL: CRC Press; 2009. [CrossRef]

7. Mahoney PF, Ryan JM, Brooks AJ, Schwab CW. Ballistic Trauma A Practical Guide. 2nd edition. London: Springer; 2005. [CrossRef]

8. Dodd MJ. Terminal Ballistics: A Text and Atlas of Gunshot Wounds. Boca Raton, FL: CRC Press; 2006. [CrossRef]
9. Nordby JJ. Scientific Foundations of Crime Scene Reconstruction Introducing Method to Mayhem. 1stedition. Boca Raton, FL: CRC Press; 2013. [CrossRef]

10. Republic of Turkey General Directorate of Highways. Technical Specifcation of Highway. Ankara; 2013.

11. Shoelace Formula. Available at: https://ipfs.io/ipfs/QmXoypizjW3WknFiJnKLwHCnL72vedxjQkDDP1mXWo6uco/wiki/Shoelace_formula.html. Accessed February 20, 2018.

\title{
ORIJIINAL ÇALIŞMA - ÖZET
}

\section{Seken av tüfeği saçma tanesi yaralanmalarının analizi ve atışın yeniden yapılandırılması \\ Dr. Gökhan İbrahim Öğünç, ${ }^{1}$ Dr. Mustafa Tahir Özer, ${ }^{2}$ Dr. Ali İhsan Uzar, ${ }^{2}$ Dr. Mehmet Eryılmaz, ${ }^{2}$ Dr. Mustafa Mercan ${ }^{3}$}

\author{
1 Jandarma ve Sahil Güvenlik Akademisi, Güvenlik Bilimleri Enstitüsü, Ankara \\ ${ }^{2}$ Gülhane Eğitim ve Araştırma Hastanesi, Genel Cerrahi Anabilim Dalı, Ankara \\ 3Jandarma Genel Komutanlığı, Kriminal Daire Başkanlığı, Ankara
}

AMAÇ: Bu çalışmada, asfalt yol yüzeyinden seken saçma tanelerinin 35 yaşındaki erkeğe isabet etmesi sonucunda ölüm olayı gerçekleşmiştir. Savcılık makamı, saçma tanelerinin sektiği noktanın tespit edilmesi için iki farklı sekme noktasından saçma tanesi dağılım kalıbı analizini talep etmiştir.

GEREÇ VE YÖNTEM: Hedeften 2 metre (A noktası) ve I metre (B noktası) uzaklıkta bulunan iki sekme noktasına I0'ar adet test atışı yapılmıştır. Atışlar sonrasında hedefte oluşan saçma tanesi dağıım kalıplarının alanları Gauss metodu ile hesaplanmıştır. Ardından, test sonuçları ile otopsi sonuçları, hedefe isabet eden saçma tanesi sayısı, dağılım kalıbı alanları ve sekme açıları bakımından karşısaştırımıştır. Ayrıca, hedefe isabet eden saçma sayısı ile saçma dağım kalıbı alanlarının otopsi verileriyle olan benzerlikleri iki kuyruklu Mann-Whitney $U$ testi ile incelenmiştir.

BULGULAR: Kurbanın vücudundan $8 \mathrm{I}$ adet saçma tanesi elde edilmiştir ve saçma tanesi dağılım kalıbının alanı $2134 \mathrm{~cm}^{2}$ 'dir. A sekme noktasına yapılan atışlarda hedefteki ortalama saçma tanesi sayısı 82. I ve saçma tanesi dağııı kalıbının alanı $2700 \mathrm{~cm}^{2}$ 'dir. B sekme noktasına yapılan atışlarda hedefteki ortalama saçma tanesi sayısı I 32.6 ve saçma tanesi dağılım kalıbının alanı $4928 \mathrm{~cm}^{2}$ 'dir. İki kuyruklu Mann-Whitney $U$ testi sonuçlarına göre A noktasından saçma tanelerinin dağıımı ile otopsi sonuçları arasında düşük seviyede $(p<0.05$ level Sig. $0.023 ; z=-2.424)$ benzerlik bulunmaktadır. Bununla beraber A noktasından seken saçma tanesi sayısı ile kurbanın vücudundan elde edilen saçma tanesi sayısı arasında benzerlik ( $p<0.05$ level Sig. $0.481 ; z=-0.808$ ) bulunmaktadır.

TARTIŞMA: Test sonuçlarına göre saçma taneleri kurbana 2 metre mesafeden sekerek isabet etmiştir.

Anahtar sözcükler: Atışın yeniden yapılandırılması; av tüfeği yaralanması; saçma tanesi sekmesi; yara balistiği.

Ulus Travma Acil Cerrahi Derg 2020;26(6):9। I-919 doi: I0.14744/tjtes.2020.76960 